\title{
Temporal variations in the wind and wave climate at a location in the eastern Arabian Sea based on ERA-Interim reanalysis data
}

\author{
P. R. Shanas and V. Sanil Kumar \\ Ocean Engineering, CSIR - National Institute of Oceanography (Council of Scientific \& Industrial Research), Dona Paula, \\ Goa 403 004, India \\ Correspondence to: V. Sanil Kumar (sanil@nio.org)
}

Received: 30 October 2013 - Published in Nat. Hazards Earth Syst. Sci. Discuss.: 6 December 2013

Revised: 27 March 2014 - Accepted: 16 April 2014 - Published: 28 May 2014

\begin{abstract}
Temporal variations in wind speed and significant wave height $(\mathrm{SWH})$ at a location in the eastern Arabian Sea are studied using ERA-Interim reanalysis data from 1979 to 2012. A shallow water location is selected for the study since measured buoy data are available close to the location for comparison with the reanalysis data. The annual mean wind speed shows a statistically significant decreasing trend of $1.5 \mathrm{~cm} \mathrm{~s}^{-1}$ year $^{-1}$, whereas a statistically insignificant increasing trend of $3.6 \mathrm{~cm} \mathrm{~s}^{-1}$ year ${ }^{-1}$ is observed for annual maximum wind speed due to the local events that altered the trend in annual maximum wind speed. Weakening of SWH during one of the peak monsoon months (August) is identified from the monthly analysis of SWH, which shows a higher upward trend in SWH during the southwest monsoon period, with an exception during August. The annual mean SWH shows a slight upward trend $\left(0.012 \mathrm{~cm} \mathrm{year}^{-1}\right)$, whereas a larger upward trend $\left(1.4 \mathrm{~cm}_{\text {year }}{ }^{-1}\right)$ is observed for annual maximum SWH. Both identified trends are statistically insignificant. The influence of tropical cyclone activity is also studied and it is found that the maximum SWH and wind speed during 1996 are directly related to the cyclonic event.
\end{abstract}

\section{Introduction}

Knowledge of the wind and wave climate is required for engineering design (e.g., ships and offshore platforms) and the shipping industry (Krogstad and Barstow, 1999; Tucker and Pitt, 2001). Wind and wave climate is assessed based on the data obtained through (i) in situ measurement, (ii) a model data set, (iii) a satellite altimeter and (iv) voluntary observing ship (VOS) data. Understanding the long-term variations in the wind and wave parameter is a key element in contemporary physical oceanography and coastal science. Long-term wind and wave records based on in situ measurements are still sparse in the Arabian Sea (AS), and only short-term records are available (Premkumar et al., 2000; Kumar, 2006; Sajiv et al., 2012; Glejin et al., 2013). A comprehensive understanding of the properties of the approaching waves and their potential changes is the major knowledge necessary for sustainable management of both offshore activities and the coastal region (Soomere and Räämet, 2011). Generally significant wave height (SWH) is used to study the wave climate at a location. Globally there have been many studies on the change in wave climate, especially in the North Pacific and North Atlantic regions (Carter and Draper, 1988; Allan and Komar, 2000; Caires and Swail, 2004; Gulev and Grigorieva, 2004; Soomere and Räämet, 2011; Vanem and Walker, 2013). Kumar and Sajiv (2010) carried out a study on variations in long-term wind speed estimates considering different decades in the AS and reported that extreme wind speed has an annual decreasing trend of $1.3 \mathrm{~cm} \mathrm{~s}^{-1}$.

As a part of the global study, Caires and Swail (2004) examined the long-term trend in SWH in the AS based on VOS data, but the long-term changes and decadal variation in wave climate in the eastern AS are not known at present. Since no regionalized study has been done on the temporal variations of SWH in the eastern AS, a study is carried out using the ERA-Interim re-analysis data set. The objective of the study is to quantify the monthly, inter-annual and decadal variability of the wind and wave climate at a location off Honnavar in the eastern AS. The analysis is based on the wind speed and SWH data obtained from ECMWF reanalysis 


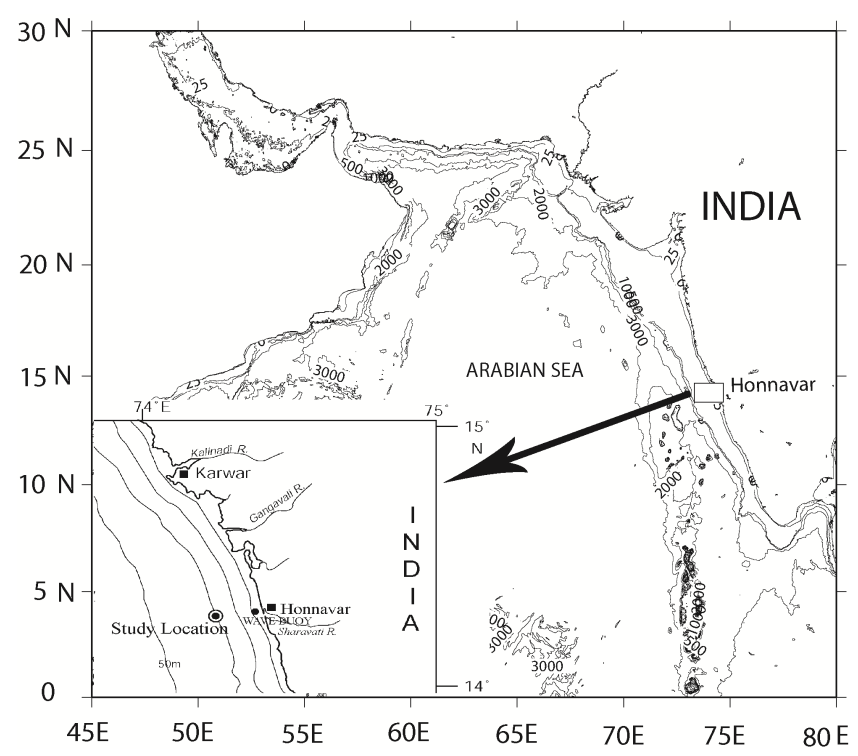

Figure 1. Study area along with location of extracted model data set and buoy.

ERA-Interim data for 34 years (1979-2012). A shallow water location $\left(14.25^{\circ} \mathrm{N}, 74.25^{\circ} \mathrm{E}\right)$ in the eastern AS is selected for the study since measured buoy data are available close to this location for comparison of the ERA-Interim SWH data. Figure 1 shows the buoy location and reanalysis data extraction location.

\section{Data and methodology}

The Indian Ocean exhibits a number of modes of climate variability, ranging from intra-seasonal to inter-annual and longer timescales, most of which are coupled to the strong seasonal cycle (Schott et al., 2009). The surface waves in the North Indian Ocean mainly depend on the wind conditions prevailing over the three different seasons, viz. southwest (SW) monsoon or summer monsoon (JuneSeptember), northeast (NE) monsoon or post-monsoon (October-January) and pre-monsoon or fair weather period (February-May) (Glejin et al., 2012). Generally high wave activity is observed during the southwest monsoon season, and is relatively calm during the rest of the season (Kumar et al., 2006).

\subsection{ERA-Interim reanalysis data}

The present study is based on the ERA-Interim global atmospheric reanalysis data that are produced by the European Center for Medium-Range Weather Forecasts (Berrisford et al., 2009; Dee et al., 2011). ERA-Interim is the first re-analysis using adaptive and fully automated bias corrections of satellite radiance observations (Dee and Uppala, 2008) and contains improvements to ERA-40 such as the
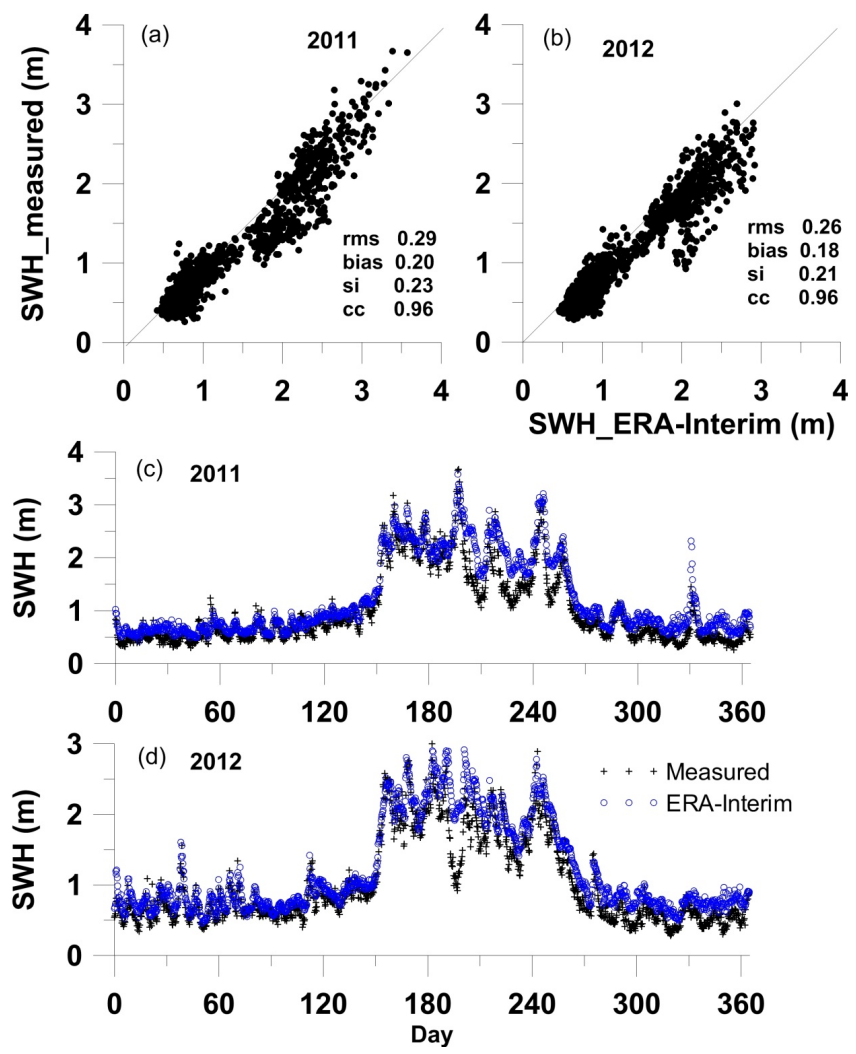

Figure 2. (a) Scatter plot showing the comparison of significant wave height based on ERA-Interim and the measured buoy data during 2011 and (b) during 2012; (c) time series plot of the significant wave height based on ERA-Interim and the measured data during 2011 and (d) during 2012.

complete use of four-dimensional variational data assimilation from various kinds of sources such as scatterometers, altimeters, US wind profiler data, etc. A detailed description of data assimilation is given in Uppala et al. (2005). The ERA-Interim reanalysis is produced with a sequential data assimilation scheme, advancing forward in time using 12hourly analysis cycles (Dee et al., 2011). A distinguished feature of the ECMWF model is its coupling through the wave height-dependent Charnock parameter to a third-generation wave model, the well-known WAM (Komen et al., 1994), which makes wave data a natural output of both the ERA-40 and ERA-Interim systems, the latter having a variational bias correction using satellite data. Wind speed and SWH downloaded for the period January 1979 to December 2012 at 6hourly intervals are used in the study. Wind speeds are derived from the zonal and meridional components of winds at $10 \mathrm{~m}$ a.s.l. We studied monthly variation in parameters (wind speed and SWH) by creating monthly data from the 6-hourly data and taking the mean of those months over a period of 34 years. 
Table 1. Trend in wind speed and significant wave height (SWH) from 1979 to 2012 in different months.

\begin{tabular}{llrrrr}
\hline \multirow{2}{*}{ Month } & \multicolumn{2}{l}{ Wind speed $\left(\mathrm{cm} \mathrm{s}^{-1}\right.$ year $\left.^{-1}\right)$} & & \multicolumn{2}{c}{ SWH $\left(\mathrm{cm} \mathrm{year}^{-1}\right)$} \\
\cline { 2 - 3 } \cline { 5 - 6 } & Mean & Max & & Mean & Max \\
\hline Jan & -0.518 & 1.426 & & -0.044 & 0.378 \\
Feb & -1.318 & -2.645 & & -0.321 & -0.153 \\
Mar & -2.234 & -2.437 & & -0.402 & -0.374 \\
Apr & -2.340 & -3.224 & & -0.417 & -0.194 \\
May & -0.830 & 2.316 & & 0.274 & 1.483 \\
Jun & -2.771 & -0.789 & & 0.138 & 1.045 \\
Jul & -1.258 & -2.578 & & 0.791 & 0.692 \\
Aug & -3.817 & -0.079 & & -0.550 & 0.111 \\
Sep & -0.137 & 6.140 & & 0.907 & 1.987 \\
Oct & -0.886 & -2.204 & & 0.028 & 0.393 \\
Nov & -1.160 & 1.498 & & -0.206 & 0.418 \\
Dec & -0.418 & 1.035 & & -0.084 & 0.034 \\
\hline
\end{tabular}

\subsection{Buoy data}

Measured wave data at $9 \mathrm{~m}$ water depth $\left(14.304^{\circ} \mathrm{N}\right.$, $74.391^{\circ} \mathrm{E}$ ) off Honnavar (Fig. 1) using a moored directional wave rider buoy from January 2011 to December 2012 are used in the present study for comparison of the ERA-Interim SWH data. The directional waverider buoy is a spherical case of $0.9 \mathrm{~m}$ diameter containing three accelerometers oriented orthogonally in one vertical direction and two horizontal directions. The vertical and horizontal (eastward and northward) displacements are obtained by double integration of the respective acceleration signal without applying a filter. The displacement data are recorded continuously at $1.28 \mathrm{~Hz}$ and the data for every $30 \mathrm{~min}$ are processed as one record. At every $200 \mathrm{~s}$, a total number of 256 heave samples are collected and a fast Fourier transform (FFT) is applied to obtain a periodogram in a frequency range of 0 to $0.58 \mathrm{~Hz}$ with a frequency resolution of $0.005 \mathrm{~Hz}$. The periodogram is smoothed using a Hanning window with $25 \%$ overlap and the spectrum is obtained. Eight consecutive spectra covering $1600 \mathrm{~s}$ are averaged and used to compute the half-hourly wave spectrum (Kumar et al., 2014). Significant wave height (SWH), which equals $4 \sqrt{m_{0}}$, and mean wave period $\left(T m_{02}\right)$, which equals $\sqrt{\frac{m_{0}}{m_{2}}}$, are obtained from the spectral moments. Here $m_{n}$ is the $n$th order spectral moment and is given as $m_{n}=\int_{0}^{\infty} f^{n} S(f) \mathrm{d} f, n=0$ and 2 , and $S(f)$ is the spectral energy density at frequency $f$.

\subsection{Comparison of reanalysis data with measured data}

Extensive inter-comparison and evaluation of wind stress estimates from the reanalysis data set (ERA-Interim) against available in situ observations have been performed for the tropical Indian Ocean (Praveen et al., 2013). Evaluation of the data is based on the comparison with available observations from the global tropical moored buoy array (McPhaden et al., 1998) and OceanSITES (http://www.OceanSITES.org,
2009) data with observations and shows that ERA-Interim data captures temporal variability with better performance $(\sim 0.86$ correlation) in near-surface parameters (wind, air surface temperature, humidity, etc.) with respect to other reanalysis data like NCEP (Kalnay et al., 1996) and NCEPDOE Reanalysis 2 (Kanamitsu et al., 2002). For the present study, the nearest available ERA-Interim SWH data to the measured in situ buoy data at Honnavar during 2011 and 2012 are used for the comparison. The comparison between the reanalysis and measured SWH data shows a very high correlation (correlation coefficient $=0.96$ ) with a small RMS error $(0.27 \mathrm{~m})$ during both years. The scattering index (SI) value is 0.23 , with a positive bias of $0.2 \mathrm{~m}$ during 2011, whereas a slightly reduced SI and bias are observed during 2012 (Fig. 2).

\section{Results and discussions}

\subsection{Variation in wind speed from 1979 to 2012}

Temporal variation in monthly maximum and mean wind speed is plotted for 34 years (Figs. 3 and 4). Monthly maximum wind speed shows a decreasing trend from February to April, June to August and in October (Table 1). Other months show an upward trend in monthly maximum wind speed. The monthly mean wind speed shows a decreasing trend in all months, with higher values during the peak southwest monsoon season (June and August). Even though a higher decreasing trend $\left(\sim 4 \mathrm{~cm} \mathrm{~s}^{-1}\right.$ year $\left.^{-1}\right)$ of mean wind speed is observed during August, the decreasing trend is less $\left(0.079 \mathrm{~cm} \mathrm{~s}^{-1}\right.$ year $\left.^{-1}\right)$ for maximum wind speed (Table 1). The highest upward trend in maximum wind speed is observed during September $\left(6.14 \mathrm{~cm} \mathrm{~s}^{-1}\right.$ year $\left.^{-1}\right)$.

An upward trend $\left(3.6 \mathrm{~cm} \mathrm{~s}^{-1}\right.$ year $\left.^{-1}\right)$ is observed for annual maximum wind speed and a decreasing trend $\left(1.5 \mathrm{~cm} \mathrm{~s}^{-1}\right.$ year $\left.^{-1}\right)$ is observed for annual mean wind speed (Fig. 5). The opposite trends observed for annual maximum and mean wind speed are due to the fact that individual local events would drive the trends of annual maxima. These individual events can alter the trend significantly. The annual maximum and mean wind speed from 1979 to 2005 has decreasing trends of 1.4 and $0.8 \mathrm{~cm} \mathrm{~s}^{-1}$ year ${ }^{-1}$, respectively. The overall negative trend in maximum wind speeds is shifted to positive by individual events in 2006 and 2007. During June 2006, high wind speed is observed with the onset of the southwest monsoon (Sanil Kumar et al., 2010). High wind speed observed in June 2007 is due to the remnant of a deep depression that developed over the western central Bay of Bengal (BoB) on 21 June and moved west-northwestwards across southern India on 22 23 June, emerging in the northeastern AS as a well-marked low-pressure area on 24 June. Hence we have estimated the 90th and 99th percentile winds, which still provide enough data points for stronger winds (which drive most of the wave 

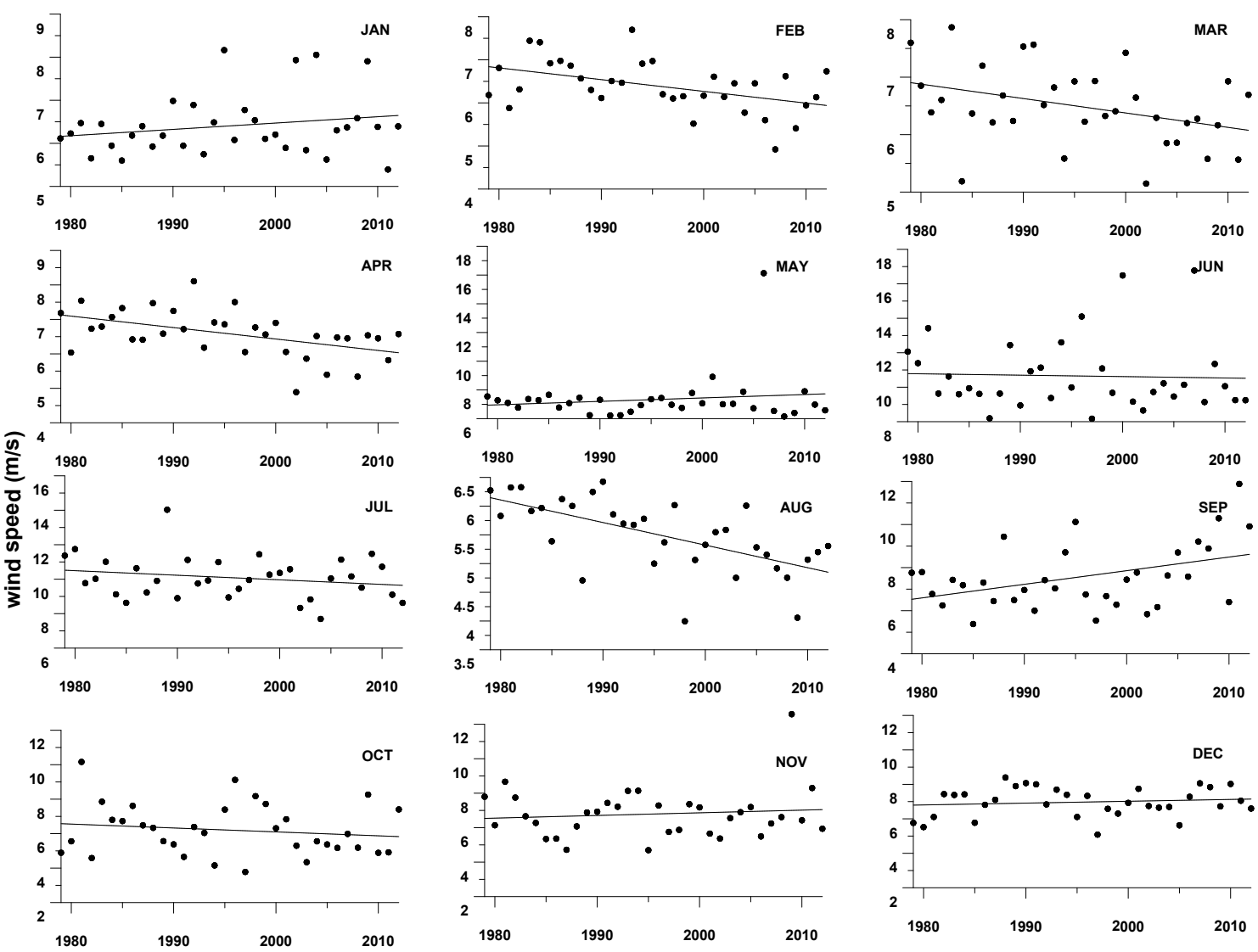

Figure 3. Temporal variation in the monthly maximum wind speed from 1979 to 2012.

action) to carry out a relevant statistical analysis. The 90th and 99th percentile values show decreasing trends (1.9 and $1.6 \mathrm{~cm} \mathrm{~s}^{-1}$ year $\left.^{-1}\right)$ similar to the trend of annual mean wind speed $\left(1.5 \mathrm{~cm} \mathrm{~s}^{-1}\right.$ year $\left.{ }^{-1}\right)$.

Statistical analysis of wind speed frequency is performed by classifying wind speed into different ranges through decadal periods from (i) 1980 to 1989 , (ii) 1990 to 1999 and (iii) 2000 to 2009 (Table 2). The study shows a decreasing trend in the frequency of occurrence of stronger winds. The weakening of strong winds is also consistent with the decreasing trend of monthly mean wind speed over 34 years.

A study on long-term variation of wind speed by Kumar and Sajiv (2010) along the AS considering different decades reported that extreme wind speed has an annual decreasing trend of $1.3 \mathrm{~cm} \mathrm{~s}^{-1}$. Some other studies also indicated a declining trend of wind speed in the last decade around the globe (Jiang et al., 2010). The decrease in the frequency of the occurrence of stronger winds (90th and 99th percentiles) in the present study also supports the hypothesis that the cyclonic activity in the AS is decreasing. Based on 118 year period data of cyclonic disturbances including cyclonic storms in AS, Shyamala and Iyer (1996) examined the decadal variability and found that the maximum number of cyclonic storms in AS occurred during the decade 1901-1910 (15), followed by 1961-1970 (14), 1971-1980 (13), 1981-1990 (3) and 1991-2000 (7). The decade 1981-1990 had the lowest frequency (3) of cyclonic storms and severe cyclonic storms. These are statistically significant decadal variabilities with a decreasing tendency in decadal frequency of cyclonic storms in AS for the three decades from 1971 to 2000. Srivastava et al. (2000) studied trends in annual cyclonic disturbances for the period 1891-1997 over the BoB and the AS and found that there is a significant decreasing trend in the annual frequency of storms over both the basins, and that the slopes of the decreasing trend are maximal during the last four decades. Singh (2001) examined the long-term trend in the frequencies of cyclonic disturbances (depression) and the cyclonic storms forming over the $\mathrm{BoB}$ and the $\mathrm{AS}$ in the monsoon season and found that the frequency of cyclonic disturbances has decreased at a rate of about six to seven disturbances per hundred years, whereas the frequency of cyclonic storms has decreased at a rate of about one to two cyclonic storms per hundred years.

\subsection{Variation in significant wave height from 1979 to 2012}

The monthly maximum and mean values of SWH for 34 years are presented in Figs. 6 and 7. Higher wave heights 

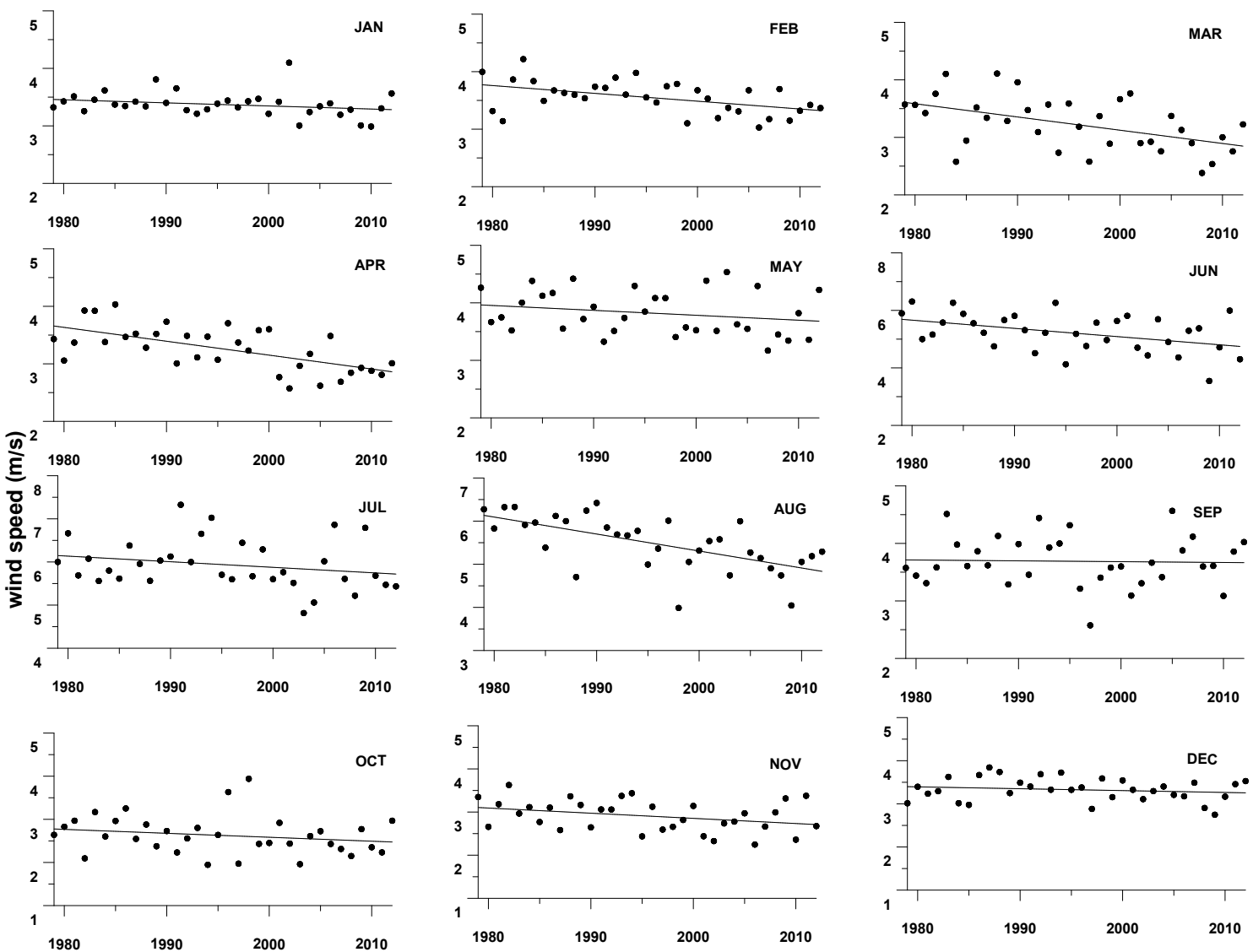

Figure 4. Temporal variation in monthly mean wind speed from 1979 to 2012.

Table 2. Frequency of occurrence of wind speed in different decades.

\begin{tabular}{lrrr}
\hline Wind speed range & $1980-1989$ & $1990-1999$ & $2000-2009$ \\
\cline { 2 - 4 }$\left(\mathrm{m} \mathrm{s}^{-1}\right)$ & Frequency (\%) & Frequency (\%) & Frequency (\%) \\
\hline $0-3$ & 30.89 & 34.40 & 38.68 \\
$3-6$ & 54.55 & 51.15 & 49.96 \\
$6-9$ & 13.61 & 13.43 & 10.46 \\
$9-12$ & 0.90 & 0.98 & 0.84 \\
$>12$ & 0.05 & 0.05 & 0.05 \\
\hline
\end{tabular}

observed during the southwest monsoon months are in line with the observation of monsoon wind speed and the earlier studies on waves in AS (Kumar et al., 2000, 2003, 2012; Sajiv et al., 2012; Glejin et al., 2013). The monthly mean SWH shows decreasing trends in August and from November to April, whereas during other months an upward trend is found (Table 1). The southwest monsoon period showed a higher upward trend in mean SWH, with an exception during August, and a maximum upward trend is observed during September $\left(0.9 \mathrm{~cm}_{\text {year }}{ }^{-1}\right)$. The significant weakening of strong winds during August also reflects the cause of weakening of mean $\mathrm{SWH}$, whereas the monthly maximum
SWH shows an upward trend for most of the months except from February to April. The decreasing trend from February to April is observed in the range $0.15-0.37 \mathrm{~cm}_{\text {year }}{ }^{-1}$. During the southwest monsoon season, the monthly maximum SWH showed a higher upward trend, with a maximum during September $\left(1.9 \mathrm{~cm} \mathrm{year}^{-1}\right)$ similar to the mean SWH.

The annual mean SWH shows a slight upward trend, with an increase of $0.012 \mathrm{~cm}$ year $^{-1}$, whereas an increasing trend of $1.4 \mathrm{~cm}$ year $^{-1}$ is observed for annual maximum SWH (Fig. 8), but both trends are found to be statistically insignificant. The trend in annual maximum SWH depends on individual events, and hence the 90th and 99th percentile values of SWH are estimated. The 90th and 99th percentile values of SWH increased by 0.15 and $0.76 \mathrm{~cm}_{\text {year }}{ }^{-1}$, respectively (Fig. 8). The increase in the annual mean is much lower than the 90th and 99th percentile and annual maximum values, suggesting larger positive trends for higher waves. The higher rate of increase for the 99th and annual maximum SWH indicates that extremes are increasing at a faster rate than the mean. Since the annual mean, maximum and the 90th and 99th percentile SWH have the increasing trend, the study shows that the SWH has an increasing trend at the location studied. 


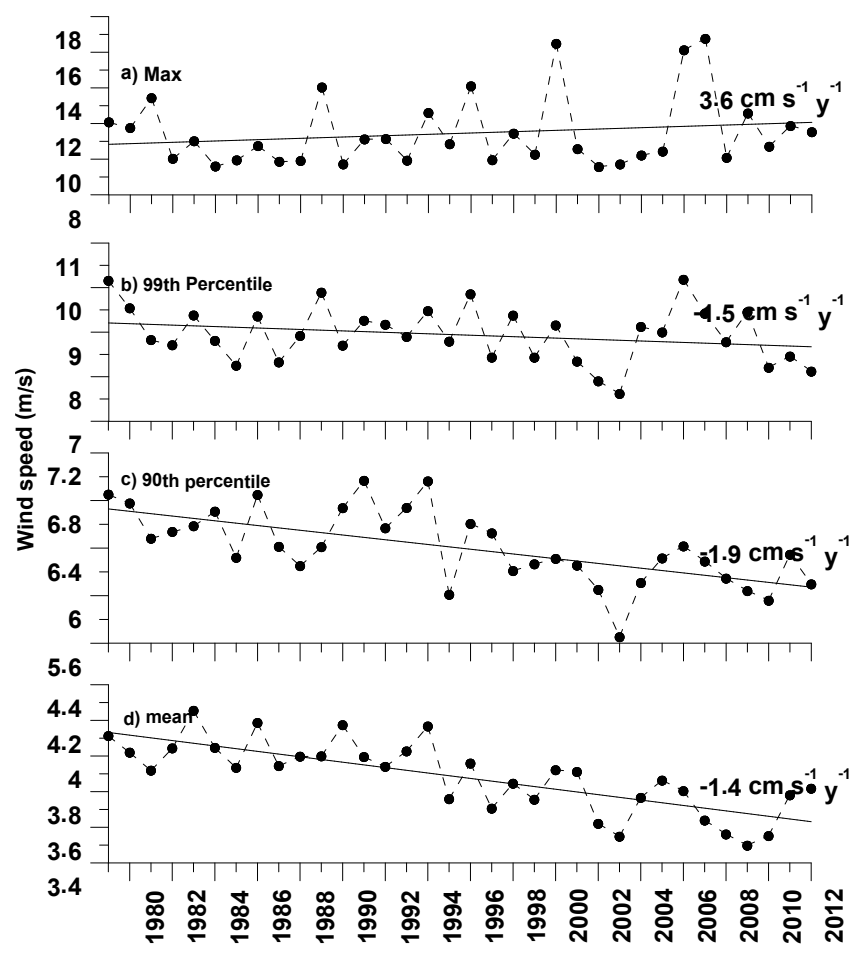

Figure 5. Long-term trend in annual (a) maximum, (b) 99th percentile, (c) 90th percentile and (d) mean wind speed from 1979 to 2012.

Similar results of increasing trends in SWH can be observed in the study of Hemer et al. (2010) for the Indian Ocean sector of the Southern Ocean. Gulev and Grigorieva (2004) studied over 100 years of ship observations and reported a slightly increasing trend in the mean wave height of $0.14 \mathrm{~m} \mathrm{decade}^{-1}$ for the North Atlantic and $0.08-$ $0.1 \mathrm{~m} \mathrm{decade}^{-1}$ for the North Pacific. Neu (1984) and Bouws et al. (1996) analyzed synoptic charts issued by the Meteorological and Oceanographic Center (Canada) for the North Atlantic and largely based on ship observations. They found a trend in mean wave height of $0.23 \mathrm{~m} \mathrm{decade}^{-1}$ (1970-1982), whereas Neu (1984) reported larger values between 0.6 and $1.4 \mathrm{~m} \mathrm{decade}^{-1}$ (1960-1985). More recent studies of buoy data in the North Pacific have shown increasing trends in average SWH between 0.05 and $0.27 \mathrm{~m} \mathrm{decade}^{-1}$ from 1979 to 1999 (Allan and Komar, 2000) and $0.15 \mathrm{~m} \mathrm{decade}^{-1}$ for the period 1976-2007 (Ruggiero et al., 2010; Young et al., 2011).

The present study shows that at the study location, the mean, 90th and 99th percentile wind speeds have a decreasing trend, whereas the corresponding SWH have an increasing trend. This contrasting result is due to the fact that waves in the eastern Arabian Sea are mainly the swells propagating from the southern Indian Ocean and Southern Ocean (Glejin et al., 2013; Sajiv et al., 2012) and hence are not directly related to the local phenomenon. Hemer et al. (2013) reported that increased Southern Ocean wave activity influences a larger proportion of the global ocean as swell propagates northwards into the other ocean basins (Hemer et al., 2013). The increase in swells at the study location is also evident from the increase in the wave period (Fig. 9). The increase in swells at the study location is due to the increase in wind speed over the Southern Ocean during the past 20 years as observed by Young et al. (2011).

\subsection{Intensity of wind speed and wave height during the peak events in AS}

Stronger storm events like cyclones produce higher waves in the region. Gray (1985) found that the northern Indian Ocean accounts for $7 \%$ of global tropical cyclones. Occurrences of tropical cyclones are more in the BoB than in the $\mathrm{AS}$, and the ratio of their frequencies is about $4: 1$ (Dube et al., 1997). From 1979 to 2008 there was an average of 4.7 cyclonic storm days per year over the AS, with 1981 , 1990, 1991, 2000, 2005, and 2008 having 0 storms, and 1998 and 2004 having more than 15 cyclonic storm days (Evan and Camargo, 2011). Hence, to examine the influence of these cyclonic events on the waves, the extreme SWH during the study period is analyzed. From 1979 to 2012 there were three peak events with SWH more than $4.5 \mathrm{~m}$ : peak1 in 1989, peak2 in 1996 and peak3 in 2000 (Fig. 10). During 1989, 1996 and 2000, the occurrence of cyclones is observed along the west coast of India. During 1989, tropical cyclone 02A developed off the west coast of India from 7 to 13 June, with a wind speed of up to $15.3 \mathrm{~m} \mathrm{~s}^{-1}$, but the peak 1 is on 23 July and is not due to the cyclone period (7-13 June). In 1996, a tropical depression formed in the AS from 9 to 12 June and developed into a tropical storm on 17 June off the west coast off India. This severe cyclonic storm from 17 to 20 June had a peak intensity of $30.6 \mathrm{~m} \mathrm{~s}^{-1}$ and generated the peak 2 event. During 2000, a depression formed at BoB on 26 November and intensified into a storm and crossed the Indian sub-continent, but the peak3 is on 7 June and not during the cyclone period (26-30 November). Simon et al. (2001) found an increase in wind speed over the AS off the Karnataka coast on 6-7 June based on the multi-frequency microwave radiometer study. The increase in the local wind speed on 6 and 7 June is the reason for the unusual increase in SWH during the peak3 event.

\subsection{Statistical trend analysis for the time series data}

A statistical analysis of the ERA-Interim wave and wind time series data has been performed to test the significance of trends during the 34-year period. A Student's $t$ test and $z$ test have been used to assess the probability distribution with $N-2$ degrees of freedom with a level of significance $(\alpha)$ fixed at $5 \%$. The result of the $t$ test and $z$ test are presented in Table 3. The null hypothesis of a zero slope is rejected for all the parameters tested here at a $5 \%$ level of significance. For all parameters as the computed $p$ value for the $t$ test and 

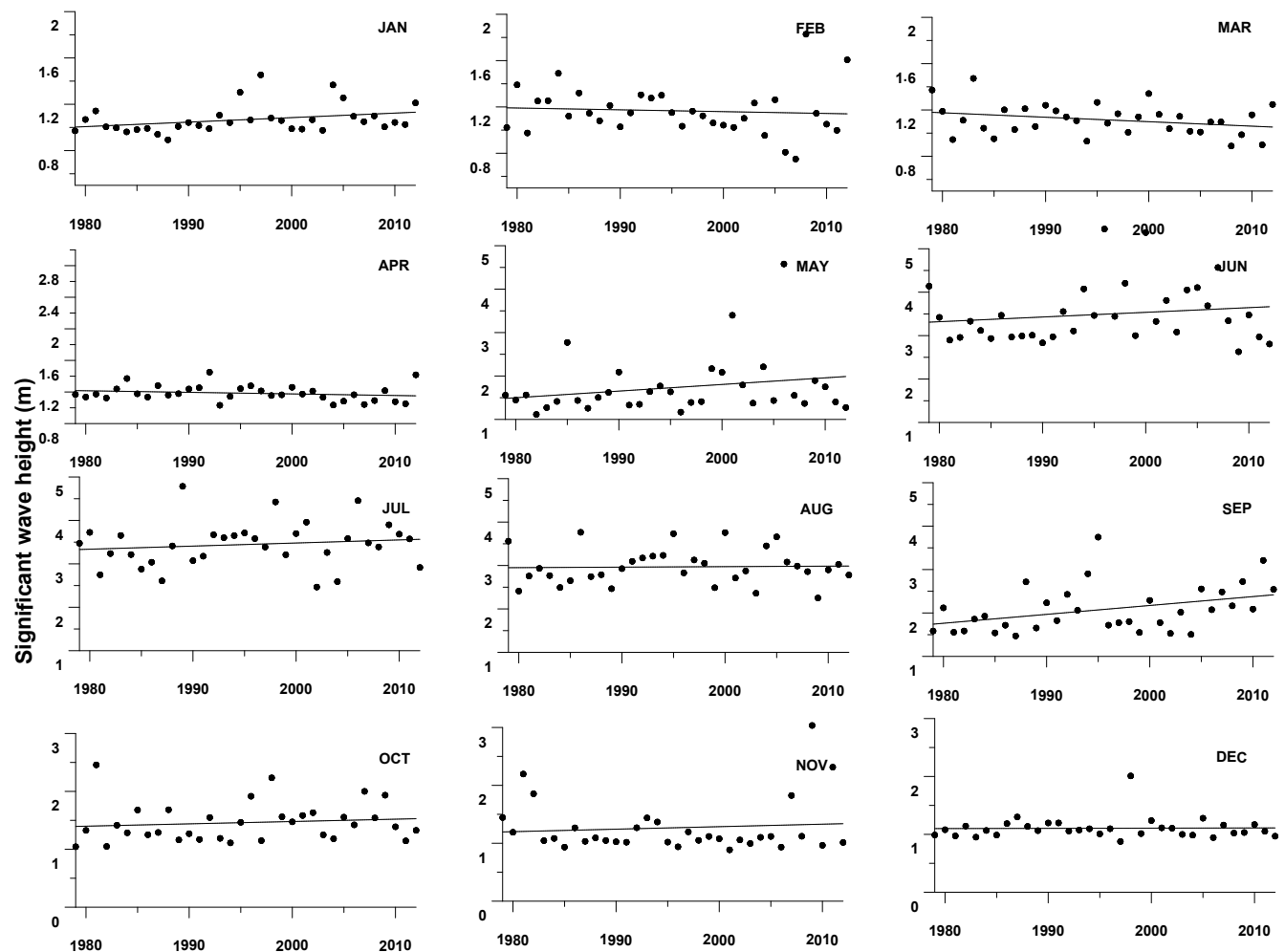

Figure 6. Temporal variation in monthly maximum significant wave height from 1979 to 2012 .
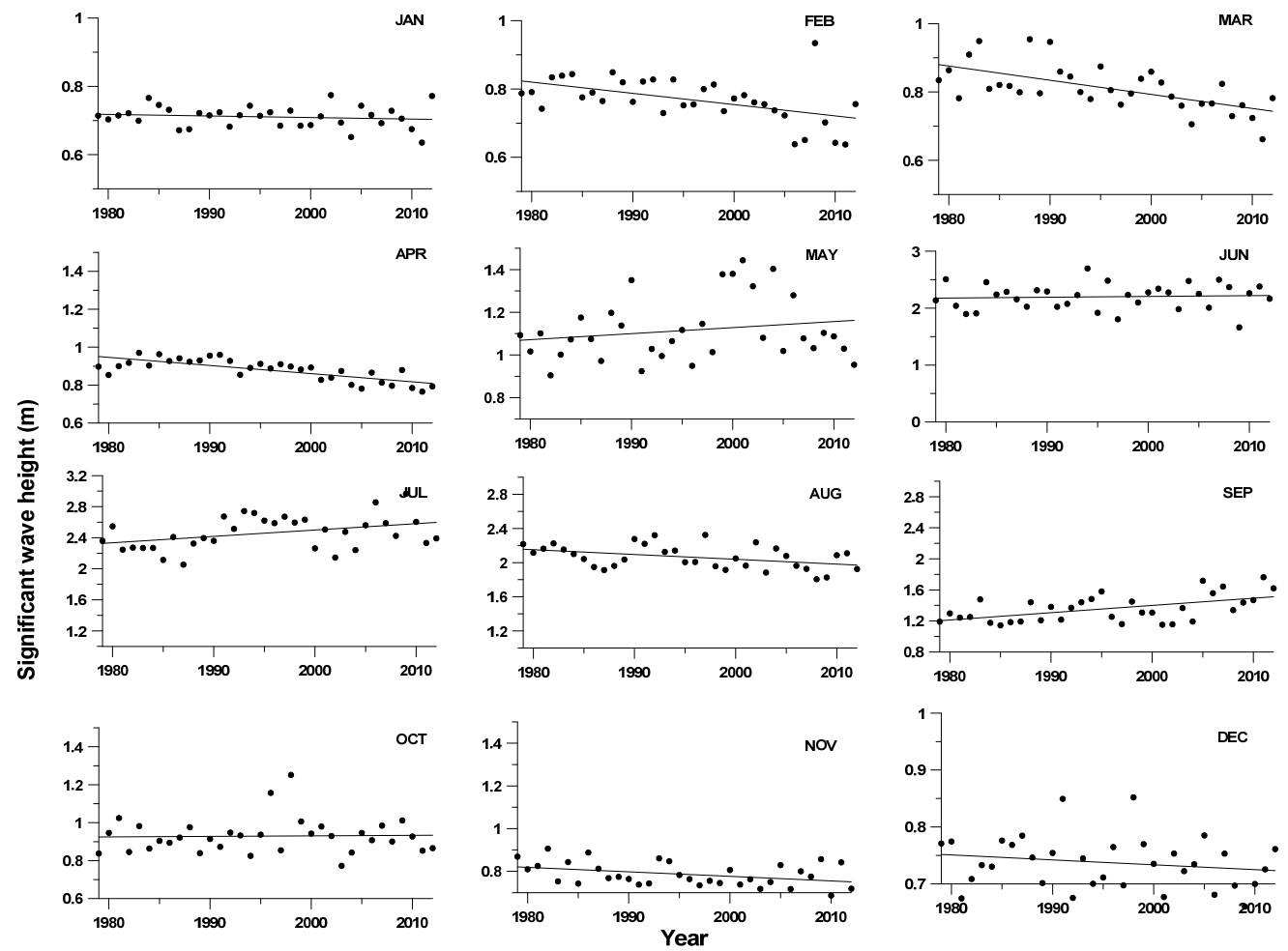

Figure 7. Temporal variation in monthly mean significant wave height from 1979 to 2012. 


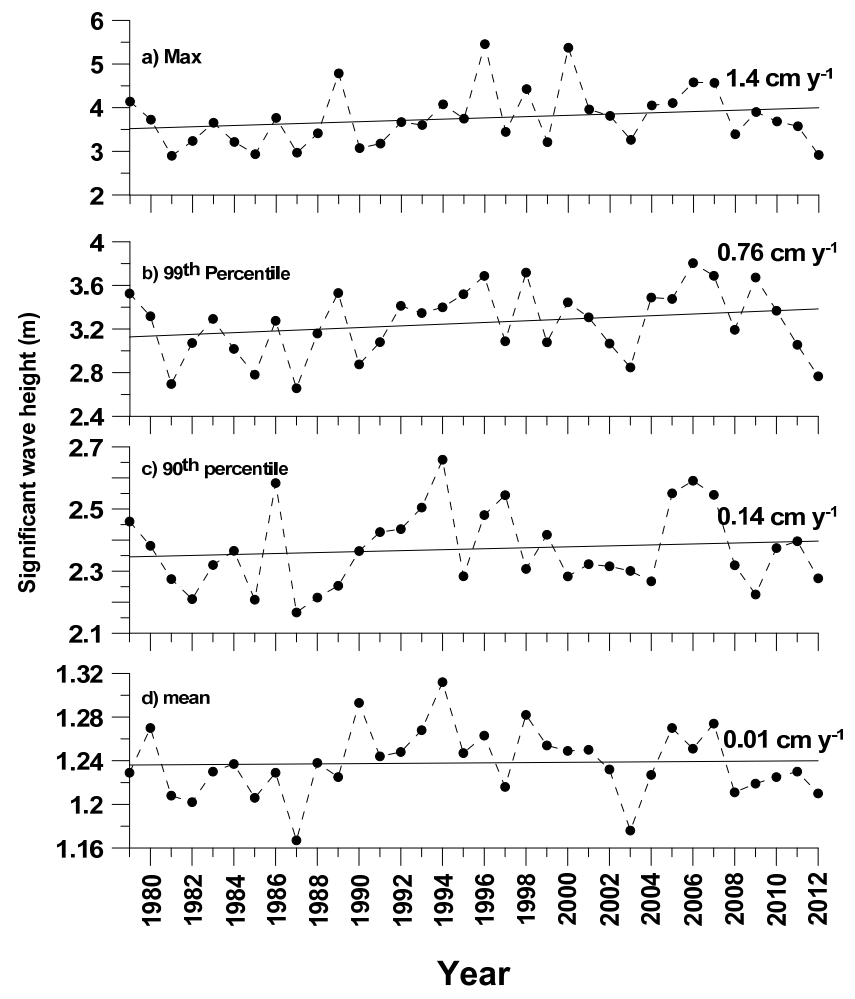

Figure 8. Long-term trend in annual (a) maximum, (b) 99th percentile, (c) 90th percentile and (d) mean significant wave height from 1979 to 2012.

$z$ test lower than the significance level $\alpha=0.05$, one should reject the null hypothesis $\mathrm{H} 0$, and accept the alternative hypothesis $\mathrm{Ha}$ (where $\mathrm{H} 0$, the difference between the means, is equal to 0 , and $\mathrm{Ha}$, the difference between the means, is different from 0). It simply means that there exists a trend with a slope in these time series and that these trends are estimated using simple linear regression. Hence the statistical significance of the identified trends has to be evaluated.

There are several statistical non-parametric tests available for testing the time series data (Hirsch et al., 1993). The main advantages of the non-parametric procedures over parametric alternatives are that the procedures can be used without making too many assumptions about the underlying concentration distributions and, in many cases, their relative simplicity. The Mann-Kendall test is a non-parametric significance test for a monotonic trend in a time series based on Kendall's tau $(\tau)$ (Mann, 1945; Kendall, 1975). We have carried out a two-tailed Mann-Kendall test with the linear fitted trend for the long-term trend of annual wave and wind parameters. The Theil-Sen slope (Sen, 1968; Theil, 1950), also known as "Kendall's slope" or the "nonparametric linear regression slope", is an alternative to the standard linear regression slope. Theil and Sen's slope estimate is also a method for robust linear regression that chooses the median slope among all lines through pairs of two-dimensional

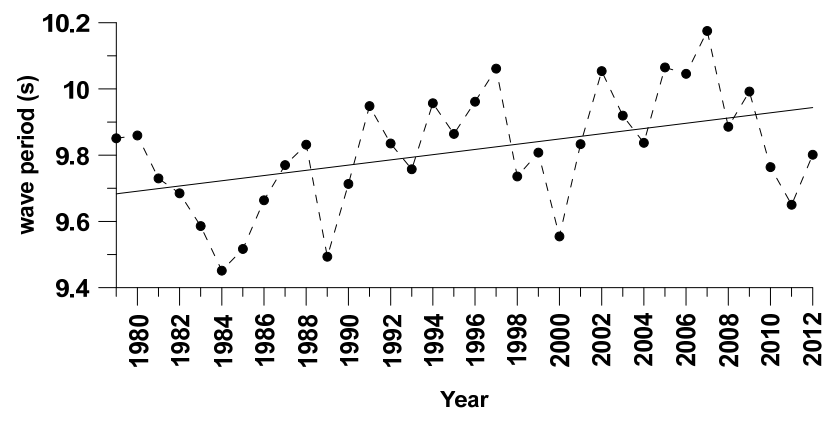

Figure 9. Variation in annual 90th percentile energy wave period from 1979 to 2012.

sample points. Kendall's tau is an alternative nonparametric statistic that can be used to test for trends (Hirsch et al., 1993). These statistics can be calculated as the number of possible pairs of years for which the ordering of the years is the same as the ordering of the annual summary statistics (the lower annual statistic occurs in the earlier year) less the number of possible pairs of years with the reverse ordering. The positive and negative values in Sen's slope indicate positive and negative trends, respectively (Table 4).

The results of all statistics performed are presented in Table 4 . As the computed $p$ value is lower than the significance level alpha $=0.05$, one should reject the null hypothesis $\mathrm{H} 0$, and accept the alternative hypothesis Ha. A statistically significant trend is found for mean wind speed and 90th percentile wind speed; the null hypothesis of a zero slope is rejected for these cases at a $5 \%$ level of significance. All other parameters (mean, maximum, 90th and 99th percentile SWH and maximum wind speed) tested failed to satisfy the significance level. Even though a small increasing trend is observed in annual mean and maximum SWH, the results of the tests show that it is statistically insignificant.

\section{Conclusions}

A long-term trend in winds and waves along the eastern AS is analyzed using the ERA-interim data set. The study shows that from 1979 to 2012, the annual mean wind speed was characterized by a decreasing trend $\left(1.5 \mathrm{~cm} \mathrm{~s}^{-1}\right.$ year $\left.^{-1}\right)$, whereas the annual maximum wind speed displays an upward trend of $3.6 \mathrm{~cm} \mathrm{~s}^{-1}$ year $^{-1}$. The annual maximum and mean wind speed from 1979 to 2005 has a decreasing trend of 1.4 and $0.8 \mathrm{~cm} \mathrm{~s}^{-1}$ year ${ }^{-1}$, respectively. The higher wind speed associated with the local depression events that occurred in AS in 2006 and 2007 shifted the trend of annual maximum wind speed from 1979 to 2012 from negative to positive. During the southwest monsoon period a higher upward trend in significant wave height (SWH) is observed with an exception during August. Annual mean SWH shows a small increasing trend $\left(0.012 \mathrm{~cm}\right.$ year $\left.^{-1}\right)$, whereas a higher increasing trend of $1.4 \mathrm{~cm}_{\text {year }}{ }^{-1}$ is observed for 

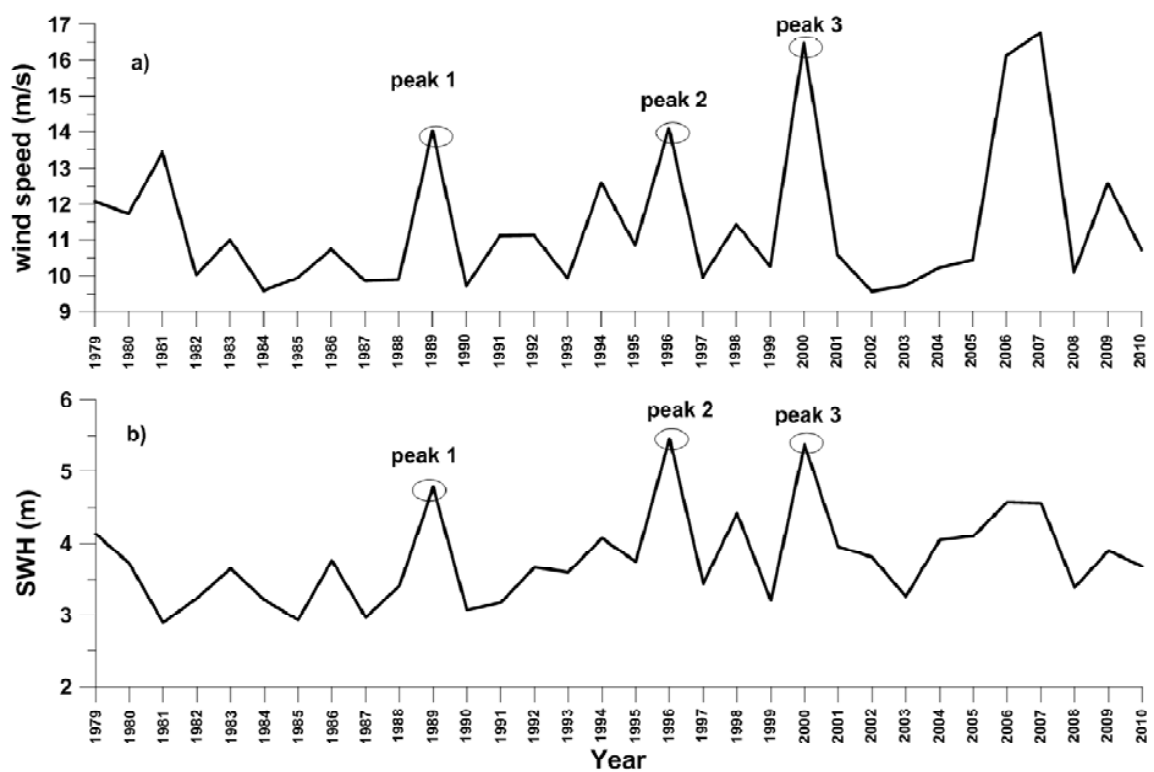

Figure 10. Temporal variation of (a) annual maximum wind speed and (b) annual maximum SWH from 1979 to 2010.

Table 3. Student $t$ test and $Z$ test for wave and wind.

\begin{tabular}{lrrrrrr}
\hline Parameter & \multicolumn{9}{c}{$t$ test } & & $Z$ test \\
\hline & $\alpha$ level & $\begin{array}{c}p \text { value } \\
\text { two tailed) }\end{array}$ & $\begin{array}{r}95 \% \text { confidence } \\
\text { interval on the mean }\end{array}$ & $\begin{array}{r}\text { Standard } \\
\text { deviation }\end{array}$ & $p$ value & $\begin{array}{r}95 \% \text { confidence } \\
\text { interval on the mean }\end{array}$ \\
\hline SWH_mean & $5 \%$ & $<0.0001$ & $(1.227,1.249)$ & 0.031 & $<0.0001$ & $(1.228,1.248)$ \\
SWH_max & $5 \%$ & $<0.0001$ & $(3.532,3.985)$ & 0.650 & $<0.0001$ & $(3.54,3.94)$ \\
Wind speed_mean & $5 \%$ & $<0.0001$ & $(3.816,3.954)$ & 0.198 & $<0.0001$ & $(3.818,3.951)$ \\
Wind speed_max & $5 \%$ & $<0.0001$ & $(10.780,12.148)$ & 1.99 & $<0.0001$ & $(10.806,12.148)$ \\
\hline
\end{tabular}

Table 4. Mann-Kendall significance test for trend analysis.

\begin{tabular}{lrrrrrr}
\hline \multirow{2}{*}{ Parameter } & Variance & Mean & Standard deviation & \multicolumn{3}{c}{ Mann-Kendall test } \\
\cline { 5 - 7 } & & & & Sen's slope & $p$ value (two tailed) & Significance \\
\hline SWH_mean & 0.0009 & 1.238 & 0.031 & 0.0001 & 0.7 & NS \\
SWH_max & 0.422 & 3.758 & 0.650 & 0.016 & 0.16 & NS \\
SWH 90th percentile & 1.67 & 2.58 & 1.29 & 0.0016 & 0.49 & NS \\
SWH 99th percentile & 1.67 & 3.47 & 1.34 & 0.008 & 0.15 & NS \\
Wind speed mean & 0.039 & 3.885 & 0.198 & -0.014 & 0.0001 & SG \\
Wind speed max & 3.99 & 11.47 & 0.40 & NS \\
Wind speed 90th percentile & 0.096 & 6.4 & 0.31 & -0.018 & 0.001 & SG \\
Wind speed 99th percentile & 0.38 & 8.95 & 0.62 & -0.019 & 0.12 & NS \\
\hline
\end{tabular}

SG: significant; NG: not significant.

annual maximum SWH. Both annual mean and annual maximum trends are statistically insignificant. The present study is based on the data covering 34 years and long time series are needed in order to assess the trends with acceptable reliability. Detailed analyses have been carried out to examine the influence of the cyclonic events on the intensity of wave activity and wind speed, finding that the peak2 event during 1996 is due to a cyclonic event and that peak3 was due to the locally formed low-pressure event. 
Acknowledgements. We thank S. W. A. Naqvi, Director, CSIR - National Institute of Oceanography, Goa for providing the encouragement to carry out the study. We thank the two reviewers for their constructive comments and suggestions that substantially improved the paper. This is NIO contribution no. 5505.

Edited by: I. Didenkulova

Reviewed by: A. Speranza and one anonymous referee

\section{References}

Allan, J. and Komar, P.: Are ocean wave heights increasing in the eastern North Pacific? Eos Trans., AGU, 47, 566-567, 2000.

Berrisford, P., Dee, D., Fielding, K., Fuentes, M., Kållberg, K., Kobayashi, S., and Uppala, S.: The ERA-interim archive, ERA Report Series, 1. Technical Report, European Centre for Medium-Range Weather Forecasts, Shinfield Park, Reading, 16, 2009.

Bouws, E., Jannink, D., and Komen, G. J.: The increasing wave height in the North Atlantic, Ocean. Bull. Amer. Meteor. Soc., 77, 2275-2277, 1996.

Caires, S. and Swail, V. R.: Global wave climate trend and variability analysis, paper presented at the 8th International Workshop on Wave hindcasting and Forecasting, US Army Eng. Res. and Dev. Cent. Coastal and Hydraulics Lab., North Shore, Hawaii, 14-19 November 2004.

Carter, D. J. T. and Draper, L.: Has the North East Atlantic become rougher?, Nature, 332, p. 494, doi:10.1038/332494a0, 1988.

Dee, D. P. and Uppala, S.: Variational bias correction in ERAInterim. ECMWF Tech. Rep. Memorandum no.575, Reading, UK, available at: www.ecmwf.int/publications (last access: 7 March 2013), 2008.

Dee, D. P., Uppala, S. M., Simmons, A. J., Berrisford, P., Poli, P., and Kobayashi, S.: The ERA- interim reanalysis: configuration and performance of the data assimilation system, Q. J. Roy. Meteor. Soc., 137, 553-597, 2011.

Dube, S. K., Rao, A. D., Sinha, P. C., Murty, T. S., and Bahulayan, N.: Numerical modelling of storm surges in the Arabian Sea, Appl. Math. Model., 9, 289-294, 1997.

Evan, A. T. and Camargo S. J.: A Climatology of Arabian Sea Cyclonic Storms, J. Climate, 24, 140-158, 2011.

Glejin, J., Kumar, V. S., Chempalayil, S. P., Singh, J., Pednekar, P., Kumar K. A., Dora, G. U., and Gowthaman, R.: Variations in swells along eastern Arabian Sea during the summer monsoon, Open J. Mar. Sci., 2, 43-50, 2012.

Glejin, J., Sanil Kumar, V., Balakrishnan Nair, T. M., and Singh, J.: Influence of winds on temporally varying short and long period gravity waves in the near shore regions of the eastern Arabian Sea, Ocean Sci., 9, 343-353, doi:10.5194/os-9-343-2013, 2013.

Gray, W. M.: Technical Document WMO/TD No. 72, WMO, Geneva, Switzerland, I, 3-19, 1985.

Gulev, S. K. and Grigorieva, V.: Last century changes in ocean wind wave height from global visual wave data. Geophys. Res. Lett., 31, L24302, doi:10.1029/2004GL021040, 2004.

Hemer, M. A., Church, J. A., and Hunter, J. R.: Variability and trends in the directional wave climate of the Southern Hemisphere, Int. J. Climatol., 30, 475-491, 2010.
Hemer, M. A., Fan, Y., Mori, N., Semedo, A., and Wang, X. L.: Projected changes in wave climate from a multi-model ensemble, Nature climate change, 3, 471-476, 2013.

Hirsch, R. M., Helsel, D. R., Cohn, T. A., and Gilroy, E. J.: Statistical analysis of hydrologic data, in: Handbook of Hydrology, edited by: Maidment, D. R., McGraw-Hill Inc., New York, Ch. 17, 17.11-17.37, 1993.

Jiang, Y., Luo, Y., Zhao, Z., and Tao, S.: Changes in wind speed over China during 1956-2004, Theor. Appl. Climatol., 99, 421-430, 2010.

Kalnay, E., Kanamitsu, M., Kistler, R., Collins, W., Deaven, D., Gandin, L., Iredell, M., Saha, S., White, G., Woollen, J., Zhu, Y., Chelliah, M., Ebisuzaki, W., Higgins, W., Janowiak, J., Mo, K. C., Ropelewski, C., Wang, J., Leetmaa, A., Reynolds, R., Jenne, R., and Joseph, D.: The NCEP/NCAR 40-year reanalysis project, Bull. Amer. Meteor. Soc., 77, 437-471, 1996.

Kanamitsu, M., Ebisuzaki, W., Woolen, J., Potter, J., and Fiorino, M.: NCEP/DOE AMIP-II Reanalysis (R-2), Bull. Amer. Met. Soc., 83, 1631-1643, 2002.

Kendall, M. G.: Rank Correlation Methods. Griffin, London, UK, 1975.

Komen, G. J., Cavalieri, L., Donelan, M., Hasselmann, K., Hasselmann, S., and Janssen, P. A. E. M.: Dynamics and Modelling of Ocean Waves, Cambridge University Press, 532 pp., 1994.

Krogstad, H. E. and Barstow, S. F.: Satellite wave measurements for coastal engineering applications, Coastal Eng., 37, 283-307, 1999.

Kumar, V. S.: Variation of wave directional spread parameters along the Indian coast, Applied Ocean Res., 28, 98-103, 2006.

Kumar, V. S. and Sajiv, C.: Variations in long term wind speed during different decades in Arabian Sea and Bay of Bengal, J. Earth Syst. Sci., 119, 639-653, 2010.

Kumar, V. S., Kumar, K. A., and Anand, N. M.: Characteristics of waves off Goa, West coast of India, J. Coast. Res., 16, 782-789, 2000.

Kumar, V. S., Anand, N. M., Kumar, K. A., and Mandal, S.: Multipeakedness and groupiness of shallow water waves along Indian coast, J. Coast. Res., 19, 1052-1065, 2003.

Kumar, V. S., Pathak, K. C., Pednekar, P., and Gowthaman, R.: Coastal processes along the Indian coastline, Current Sci., 91, 530-536, 2006.

Kumar, V. S., Glejin, J., Dora, G. U., Sajiv, C. P., Singh, J., and Pednekar, P.: Variations in nearshore waves along Karnataka, west coast of India, J. Earth Sys. Sci., 121, 393-403, 2012.

Kumar, V. S., Dubhashi, K. K., and Nair, T. M. B.: Wave spectral characteristics off Gangavaram, East coast of India, J. Oceanogr., 70, 307-321, doi:10.1007/s10872-014-0223-y, 2014.

Mann, H. B.: Nonparametric tests against trend, Econometrica, 13, 245-259, 1945.

McPhaden, M. J., Busalacchi, A. J., Cheney, R., Donguy, J. R., Gage, K. S., Halpern, D., Ji, M., Julian, P., Mayers, G., Mitchum, G. T., Niiler, P. P., Picaut, J., Reynolds, R. W., Smith, N., and Takeuchi, K.: The tropical ocean-global atmosphere (TOGA) observing system: a decade of progress, J. Geophys. Res., 103, 14169-14240, 1998.

Neu, H. J. A.: Interannual variations and longer-term changes in the sea state of the North Atlantic from 1970 to 1982, J. Geophys. Res., 89, 6397-6402, 1984. 
OceanSITES: User's Manual, available at: http://www.oceansites. org/docs/oceansites-user-manual.pdf, last access: December 2009.

Praveen, K. B., Vialard, J., Lengaigne, M., Murty, V. S. N., McPhaden, M. J., Cronin, M., Pinsard, F., and Gopala Reddy, K.: TropFlux wind stresses over the tropical oceans: evaluation and comparison with other products, Clim. Dyn., 40, 2049-2071, 2013.

Premkumar, K., Ravichandran, M., Kalsi, S. R., Sengupta, D., and Gadgil, S.: First results from a new observation system over the Indian Seas, Curr. Sci., 78, 323-330, 2000.

Ruggiero, P., Allan, J. C., and Komar, P. D.: Increasing wave heights and extreme-value projections: the wave climate of the U.S. Pacific Northwest, Coastal Eng., 57, 539-552, 2010.

Sajiv, P. C., Kumar, V. S., Glejin, J., Dora, G. U., and Vinayaraj, P.: Interannual and seasonal variations in near shore wave characteristics off Honnavar, west coast of India, Curr. Sci., 103, 286-292, 2012.

Sanil Kumar, V., Sajiv Philip, C., and Balakrishnan Nair, T. N.: Waves in shallow water off west coast of India during the onset of summer monsoon, Ann. Geophys., 28, 817-824, doi:10.5194/angeo-28-817-2010, 2010.

Schott, F. A., Xie, S. P., and McCreary Jr., J. P.: Indian Ocean circulation and climate variability, Rev. Geophys., 47, RG1002, doi:10.1029/2007RG000245, 2009.

Sen, P. K.: Estimates of the regression coefficient based on Kendall's tau, J. Amer. Statist. Assoc., 63, 1379-1389, 1968.

Shyamala, B. and Iyer, B. G.: Statistical study of cyclonic disturbances in Arabian Sea, Proceedings of TROPMET-1996, Vishakhapatnam, 14-17 February, 1996.

Simon, B., Joshi, P. C., Thapliyal, P. K., Pal, P. K., Sarkar, A., Bhatia, R. C., Jain, R. K., Singh, D., Mukherjee, S. K., and Gupta, H. V.: Monsoon onset-2000 monitored using multi-frequency microwave radiometer on-board Oceansat-1, Curr. Sci., 81, 647651,2001 .
Singh, O. P.: Long term trends in the frequency of monsoonal cyclonic disturbances over the North Indian Ocean, Mausam, 52, 655-658, 2001.

Soomere, T. and Räämet, A.: Long-term spatial variations in the Baltic Sea wave fields, Ocean Sci., 7, 141-150, doi:10.5194/os7-141-2011, 2011.

Srivastava, A. K., Sinha Ray, K. C., and De, U. S.: Trends in the frequency of cyclonic disturbances and their intensification over Indian seas, Mausam, 51, 113-118, 2000.

Theil, H.: A rank-invariant method of linear and polynomial regression analysis, I. Proceedings of the KoninklijkeNederlandseAkademic van Wetenschappen Series A, 53, 386-392,1950.

Tucker, M. J. and Pitt, E. G.: Waves in Ocean Engineering, Elsevier ocean engineering book series vol. 5, Elsevier, Amsterdam, 521 pp., 2001.

Uppala, S. M., Kållberg, P. W., Simmons, A. J., Andrae, U., da Costa Bechtold, V., Fiorino, M., Gibson, J. K., Haseler, J., Hernandez, A., Kelly, G. A., Li, X., Onogi, K., Saarinen, S., Sokka, N., Allan, R. P., Andersson, E., Arpe, K., Balmaseda, M. A., Beljaars, A. C. M., van de Berg, L., Bidlot, J., Bormann, N., Caires, S., Chevallier, F., Dethof, A., Dragosavac, M., Fisher, M., Fuentes, M., Hagemann, S., Hólm, E., Hoskins, B. J., Isaksen, L., Janssen, P. A. E. M., Jenne, R., McNally, A. P., Mahfouf, J.F., Morcrette, J.-J., Rayner, N. A., Saunders, R. W., Simon, P., Sterl, A., Trenberth, K. E., Untch, A., Vasiljevic, D., Viterbo, P., and Woollen, J.: : The ERA-40 re-analysis, Q. J. Roy. Meteorol. Soc., 131, 2961-3012, doi:10.1256/qj.04.176, 2005.

Vanem, E. and Walker, S. E.: Identifying trends in the ocean wave climate by time series analyses of significant wave height data, Ocean Eng., 61, 148-160, 2013.

Young, I. R., Zieger, S., and Babanin, A.: Global trends in wind speed and wave height, Science, 332, 451-455, 2011. 